\title{
Traditional Enrichment Planting in Agroforestry Marginal Land Gunung Kidul, Java, Indonesia
}

\author{
Priyono Suryanto (Corresponding author) \\ Faculty of Forestry, Universitas Gadjah Mada \\ Yogyakarta, Indonesia \\ Tel: 62-274-550-542Ｅ-mail: psuryanto@ugm.ac.id
}

\author{
Eka Tarwaca Susila Putra \\ Faculty of Agriculture, Universitas Gadjah Mada \\ Yogyakarta, Indonesia
}

Received: December 2, 2011

Accepted: January 5, 2012 Published: February 1, 2012

doi:10.5539/jsd.v5n2p77

URL: http://dx.doi.org/10.5539/jsd.v5n2p77

\begin{abstract}
Traditional agroforestry management seems to be perfunctory thus the developed one is that a particular area is planted with as much trees as possible. Assumption developed among agroforester farmers is that more trees planted the greater the production or the economic value are. One of the traditional silviculture actions in agroforestry systems is enrichment planting. This study aims to identify the practice of enrichment planting which is developed in agroforestry management and to devise the schemes to increase more prospective enrichment planting. The research was conducted in Gunung Kidul, Java, Indonesia which includes three zones namely the Batur Agung (Nglanggeran Village), Ledok Wonosari (Gari Village) and Gunung Seribu (Jetis Village). Data sampling method is done by purposive random sampling way. In each village it is selected 30 units of agroforestry land consisting of 10 initial agroforestries, 10 intermediate agroforestries and 10 advanced agroforestries. Analysis includes site conditions, microclimate, evolving patterns of agroforestry and traditional silvicultural practices. The result shows that the practice of enrichment planting traditionally is still limited to the consideration of the tree numbers increase in agroforestry systems. Furthermore enrichment planting has not been followed by intensive silvicultural actions. Based on these considerations it is necessary to make innovation to increase the agroforestry productivity (Batur Agung Zone) with intensive silviculture that synergizes enrichment planting with pruning, commercial thinning and tebang butuh through the schemes: 1) Agroforestry for food, 2) Agroforestry transition from food-based initial agroforestry to advanced agroforestry and 3) Acceleration of initial agroforestry to advanced agroforestry. As for Ledok Wonosari and Gunung Seribu Zone through the schemes: 1) Acceleration of initial agroforestry to full teak advanced agroforestry and 2) The transition from initial to advanced agroforestry with enrichment. With the scheme of this traditional silviculture technology can enhance the role of agroforestry as a last resort of forest management outside the forest.
\end{abstract}

Keywords: Agroforestry, Traditional, Enrichment planting, Intensive silviculture

\section{Introduction}

Agroforestry has strategic position as the harmonious and prospective solution for the interests of natural resource management based on the demands to produce more commodities both in forestry and agriculture. Agroforestry is a natural resource management system that is dynamic and based on ecology, with efforts to integrate trees in farming and ranch to get the diversity and sustainability of production in order to increase social, economic, and environmental benefits (Leakey, 2006). Agroforestry has more species diversity varieties compared to traditional agricultural systems. However its level of species diversity is still lower compared to tropical forest. This rich diversity makes it considered resilient ecologically and thus makes it able to perform better ecological functions (Olson et al., 2000; Vandermeer, 2002).

Traditional agroforestry is defined as "any farming system, where the trees which comes from planting or stands maintenance that has been available as an integrated part of socio-economic and ecological agroecosystem" (Thaman, 1989). Traditional agroforestry practices play roles in biodiversity conservation through in situ 
conservation for trees on farms, pressure reduction on remnant forests, and the suitable habitat supply for a number of plant and animal species on farmland (Atta-Krah et al., 2004; Ouinsavi et al., 2005; Acharya, 2006; McNeely \& Schroth, 2006). Traditional agroforestry systems have less diversity and it is also less dense than natural forest, (Backes, 2001; McNeely \& Schroth, 2006; Okay \& Odebiyi, 2007), nonetheless it is still very useful to know about them as the support for sustainable biodiversity conservation.

Agroforestry management that is developed seems to be "perfunctory" as it can be seen from the fact that in a particular area as much as possible trees are planted. Assumption developed among agroforester farmers is that with more trees the production or economic value will be greater. While in fact the higher the density of trees the growth will be focused in height increase thus the trees' diameter will be small. One of the traditional silviculture actions in agroforestry systems is by planting enrichment. But the practice is still limited by planting patch up seeds. Agroforestry systems regeneration done by farmers derived from natural saplings (as much as $72 \%$ ) and it is only as much as $12 \%$ that comes from qualified seeds (Roshetko \& Manurung, 2009).

In the effort to improve agroforestry productivity then the important step that needs to be done is the implementation of intensive silviculture techniques. Harmonious and prospective agroforestry management has $4 \mathrm{i}$ pillars namely intentional, intensive, integrated and interactive (Gold et al., 2000). This study aims to identify the practice of enrichment planting that is developed in the agroforestry management and to devise schemes to increase more prospective enrichment planting.

\section{Methods}

Geographically, Gunung Kidul located at $7^{\circ} 46^{\prime} \mathrm{SL}-8^{\circ} 09^{\prime} \mathrm{SL}$ and $110^{\circ} 21^{\prime} \mathrm{BT}-110^{\circ} 50^{\prime} \mathrm{BT}$, with an area of $1485.36 \mathrm{~km}^{2}$, or approximately $46.63 \%$ of the area of the Province of Yogyakarta Special Region. Based on its topography condition Gunungkidul divided into 3 (three) zones, namely: 1) the North Zone called as the Batur Agung Zone (ZBU) with height of 200-700m above sea level, 2) Central Zone called Ledok Wonosari Zone (ZLW) with height of 150-200m asl and South Zones called Gunung Seribu/ Duizon gebergton Zone (ZGS) with height of $0-300 \mathrm{~m}$ above sea level (Gunung Kidul in figures, 2010). In this study three villages are selected; namely the ZBU (Nglanggeran Village), ZLW (Gari Village) and ZGS (Jetis Village).

Data sampling method is done by purposive random sampling method. In each selected village 30 units of agroforestry land which consists of 10 initial agroforestries, 10 intermediate agroforestries and 10 advanced agroforestries are chosen. Initial, intermediate, and advanced agroforestry categorization is according to Suryanto et al. (2006). Agroforestry development model based on canopy thickness visualized with grayscale color gradient range is depicted in Figure 1.

Nutrient mineral availability information in the agroforestry zone is detected by using soil analysis method. The analysis is carried out towards all the elements that are included into essential nutrient groups (macro and micro). Soil samples are taken proportionally, including rhizosphere zone of perennials and seasonal plants. Soil profiling is also performed in all agroforestry zones.

Profiling is necessary to know the characteristics of soil physics, since this nature determines the stand growth rate (annual or seasonal), especially the roots. Several microclimate factors in agroforestry zones that are recorded include soil and air temperature, relative humidity, soil moisture and sunlight intensity. Each microclimate component was observed at several levels (surface, medium and depth).

The data were analyzed using the Analysis of Variance (ANOVA) at 5\% level and continued with the Duncan's Multiple Range Test (DMRT) if the result was found to be significant. All the analyses were performed using the General Linear Model Procedure (PROC GLM) (SAS Institute, 1990).

Agroforestry practices are generally identified by model assessment developed and detailed information about the enrichment planting practices done by agroforest farmers. The result of this data is used as the basic in preparing the agroforestry productivity increase scheme through the more prospective enrichment planting.

\section{Results}

Daily air temperature at Gari is higher than in Jetis and Nglanggeran, while Nglanggeran has the lowest daily air temperature compared to two other zonings. Associated with daily air humidity, Gari daily humidity levels lower than Jetis and Nglanggeran (Table 1).

Solar radiation intensity is also different between the agroforestry zonings. Jetis gets greater solar radiation than Nglanggeran and Gari. Therefore, Jetis has better solar radiation availability level than Nglanggeran and Gari. Nglanggeran, Gari, and Jetis have a homogeneous root distribution patterns. It is an indicator that all three zones have the same rate of root growth level (Table 1). 
Land characters in all three zones showed that in Nglanggeran have better physical and chemical soil properties than Gari and Jetis (Table 2), so its level of environmental resources availability to support growth, development and yield of plants (or trees) is the most optimal. The most distinguishing character among the three agroforestry clusters is the composition of soil compiler fractions. Land in Jetis is dominated by clay fraction with a few fractions of dust and sand. These fractions result the land in Jetis region has very poor drainage during the rainy season, which result in land prone to experience saturation. The relatively similar condition seen in the land in Gari zone; land in Gari zone is also very much dominated by the clay fraction, so the drainage in this zone is not very good. Land condition which is prone to water saturation is less ideal for the growth and development of plants.

The ideal land condition exists in Nglanggeran where the composition of clay fraction, dust and sand is quite balanced, none of them is too dominant. The composition of the balanced soil compiler fractions is a guarantee for the achievement of growth, development as well as maximum crop result.

Microclimate conditions in various types of agroforestry (initial, intermediate and advanced) showed a difference. Initial-AF had a greater solar resource than the intermediate AF and advanced AF. Meanwhile, solar resource availability at the advanced $\mathrm{AF}$ was the lowest compared to the initial and intermediate stages. The condition was a consequence to the increase in air temperature and decrease in air humidity in the initial agroforestry (Table 3).

Temperature in the initial agroforestry was higher than the one at intermediate or advanced stage, while the opposite condition occured in variable humidity. Air humidity at the initial agroforestry stage was much lower than at the intermediate and advanced stages. Rooting densities were significantly different between agroforestry stages. Advanced agroforestry stage had the highest root density followed by the intermediate and initial stages. Meanwhile, at the initial agroforestry stage, rooting was at the lowest density compared with advanced and intermediate stages (Table 3). These data indicated that the initial agroforestry was the most likely to be planted by various types of seasonal food crops as the interval crop.

Microclimate conditions especially air temperature, air humidity and solar radiation intensity differed significantly between the open zone, semi open zone and under the stand (Table 4). The highest air temperature and solar radiation intensity occured in the open zone region, while the air humidity in the zone is the lowest compared to semi open zone and under the stand.

Under the stand zone had lower air temperature and solar radiation intensity than the open or semi open zone. Under the stand zone was more humid compared to the open or semi open zone. The open or semi open zone and under the stand zone had a significantly different microclimate conditions, however, rooting density (root distribution) in all of the three zones were in the same rate (Table 4).

Typology of initial, intermediate, and advanced agroforestry in the three clusters showed the same tendency. Initial agroforestry was characterized by large crop area in the top over $50 \%$ of the total area of land units. While the intermediate agroforestry crop area, was approximately $25-50 \%$ of the total area of land units. In the advanced agroforestry, crop area existence has been ignored because a transition had occurred after the planting enrichment (Figure 2).

The practice of planting enrichment in the three clusters showed a different tendency, especially in the Nglanggeran Village, while in the Gari and Jetis village showed a similarity (Figure 3). The type used for the planting enrichment of Nglanggeran village is more directed at the number of trees increase as well as the type number. Meanwhile the type in the Gari and Jetis village was only limited on the number of trees adding per acre. Falcataria moluccana, Swietenia mahagoni, Acacia sp and Dalbergia latifolia keeling were chosen as the plant types for the enrichment planting in the Nglanggeran Village. The type in Gari and Jetis village was dominated by teak plantation. In addition the Nglanggeran Village also chose other types of multi-purpose trees species (MPTS) such as Durian, Parkia speciosa, Gnetum gnemon, Nephelium lappaceum and Cacao.

Cropping pattern in the enrichment planting system in the Nglanggeran Village was more regular with planting locations not only on the interface (crop area) but also in the woods. While in Gari and Jetis village, the cropping pattern was irregular with planting location that was only focused on the interface. General agroforestry stand management in Nglanggeran was more intensive compared to the one in Gari and Jetis (Figure 3).

Based on the traditional practices consideration of enrichment planting then it is necessary to do strategy for more prospective agroforestry management.

1) Agroforestry for food: This scheme continued to pursue agroforestry management to be always in an active condition to bring the seasonal crops. Silvicultural action which was very essential to support this scheme was 
the intensive pruning and the commercial thinning. With this scheme of agroforestry was always in a state of initial agroforestry which was active throughout the management (Figure 4).

2) Agroforestry transition from food to advance. In this scheme agroforestry management experienced interest orientation change of the farmers for seasonal crop production into advanced agroforestry. Selection of enrichment planting scheme would provide two models of advanced agroforestry forms. If in the enrichment planting species used MPTS then the final form of its advanced agroforestry was mixed garden. Meanwhile, if the type used was trees then the final form of its advanced agroforestry was the full trees (Figure 4).

3) Acceleration of advanced agroforestry. In this scheme, each agrofrestry stages' period shortening happened. Initial agroforestry developments was directly continued with enrichment planting actively and continuously developed into advanced agroforestry. Achievement in the advanced agroforestry in the form of mixed garden or full trees was faster than schemes 1 and 2 (Figure 4). Harvesting model followed by traditional approach with popular tebang butuh (based on the urgency of the farmers' needs harvesting).

The above scheme is different from the scheme developed for the Gari and Jetis village. In this scheme there are two types, namely:

1) The transition from early to advanced agroforestry with enrichment. In this scheme teak planted selection in the crop area would be done. This condition continued to develop into full trees advanced agroforestry with teak as the dominant species (Figure 5).

2) Acceleration of full teak advanced agroforestry. In this scheme acceleration is carried out from initial agroforestry towards the intermediate by directly conducting enrichment planting. The development of advanced agroforestry information was more quickly with full teak.

\section{Discussion}

Batur Agung zone (ZBA) had a fertile footprint with soils dominated by latosol, with daily temperature conditions and low solar radiation with high daily humidity. Ledok Wonosari Zone (ZLW) has a footprint of less fertile with mediteran and grumosol soil type, daily temperature and high solar radiation with low humidity. While Gunung Seribu Zone (ZGS) had infertile footprint dominated by karst area, has high daily solar radiation and temperatures with low humidity.

These kinds of microclimate and site conditions resulted on the developed agroforestry typology. The ZBA agroforestry had more types and the active initial agro-forestry schemes sustainability could be done throughout the management. While at the ZGS and ZLW developed agroforestry based on teak had shorter initial agroforestry sustainability. However, the third zone had a similar tendency of the existed resources situational which existed in initial intermediate and advanced agroforestry. Agroforestry resource status at the initial stage was better than the one at the intermediate and advanced agroforestry. The last agroforestry has the intensity of light and lower temperatures with high humidity.

More detail, the resources condition in each zone in the initial, intermediate, and advanced agroforestry showed a similar trend in ZBA, ZLW and ZGS. The line of trees zone possessed a limited level of resources. Roots in this zone also showed higher numbers so it had high competition. Trees which affected seasonal crop growth by altering the likelihood resources such as light, soil nutrients and water (Scholes \& Walker, 1993). While the open zone (no shade) had sufficient resource to the cultivation of seasonal crops.

Agroforestry typology developed traditionally by agroforest farmers in the three zonings showed that information in ZBA with fertile site conditions dominating held during the initial agroforestry management. The uniqueness of this agroforestry silvicultural technique was arranging the existing rescource sharing so that it can be utilized in a balanced way between the components of trees and seasonal crops (Suryanto et al., 2006). Thus the space arrangement both vertically (RV) and horizontal (RH) became the important key in agroforestry systems (Suryanto et al., 2005). According to Tohari (2004) in intercropping planting, inter-constituent plant species interacted both horizontally and vertically to get growth factors such as sunlight, water and nutrient elements of the environment. Its biodiversity levels were also higher than the ZLW and ZGS. Agroforestry trajectories in ZLW and ZGS on initial agroforestry to the intermediate and advanced were faster and the final model developed was full trees. Sanchez (1995) identified the purpose of agroforestry to use tree to capture the resources that were not used by crops.

Traditional enrichment planting practice developed by farmers on ZBA had more intensive management than ZLW and ZGS. Farmers on ZBA chose the types of MPTS and the final form of agroforestry that was developed with two models namely full trees and mixed garden. Enrichment planting technique developed was done more in the previous interface that was previously used for crop area. According to Huxley (1985) the key to understand 
the agroforestry system control and the plant response towards the environmental components in agroforestry systems was tree/crop interface.

However, in general agroforestry developed in the three zones showed a very specific management which seemed to be 'perfunctory'. Space arrangement and tree management with silvicultural actions has not been intensive to increase productivity agroforestry. Based on these considerations it is necessary to do intensive agroforestry schemes (Suryanto et al., 2010). Enrichment planting practices developed may be directed in the effort to increase productivity acceleration through the schemes: 1) Agroforestry for food, 2) Agroforestry transition from the food based initial agroforestry to advanced agroforestry and 3) Acceleration of initial agroforestry towards advanced agroforestry.

The regime of space arrangement with intensive pruning becomes an important key in this scheme. In addition silvicultural regimes developed namely tebang butuh is synergized with commercial thinning and pruning. One of the important silviculture techniques in agroforestry management is canopy pruning especially to hold its status which is always active in the level of initial agroforestry (Suryanto et al., 2006). In general pruning technique used is variable lift pruning (Montagu et al., 2003) although it is more complex compared to fixed-lift pruning (Suryanto et al., 2011a).

While on Ledok Wonosari and Gunung Seribu with schemes developed are: 1) acceleration of initial agroforestry to full teak advanced agroforestry and 2) the transition from initial to advanced agroforestry with enrichment. The use of qualified teak seedlings become an important key to improve the productivity of teak based agroforestry. Implementation of commercial thinning needs to be done regularly to provide growing space for existing stand. Tebang butuh in this scheme should be based on the space improvement not only based on the needs of money.

This scheme can be used as a reference for the more prospective renewal agroforestry with intensive management of enrichment planting based on agroforest farmers' traditional knowledge. Silviculture agroforestry regime is not only maintain the agroforestry stand, but also biodiversity and the pro-poor target (Suryanto et al., 2011b). Local ecological knowledge can contribute to the development of technological innovation (Mulyoutami et al., 2004; Joshi et al., 2005), the biodiveristy and ecosystem conservation and sustainable natural resources exploitation (Berkes et al., 2000). This traditional silvicultural innovation practice is expected to be the practice for agroforestry management, which in turn passed down to the subsequent generations through communal learning or link farm. One of the approaches to accelerate agroforestry status is through farmer learning; farmer to farmer concept which is popular as "Farm Link" (Shelton et al., 2009). It is done to anticipate the discontinuation of agroforestry innovation management. In the process of knowledge formation, sometimes some traditional or indigenous values which are usually passed down from generation to generation are not carried over (Joshi et al., 2003; Joshi et al., 2004).

\section{Conclusion}

Traditional enrichment planting practice is still limited to the consideration of the number of tree increase in agroforestry systems whether on initial, intermediate and advanced agroforestry. Furthermore enrichment planting action has not been followed by intensive silviculture. Based on these considerations it is necessary to make innovations to increase the agroforestry productivity (Agung Batur Zone) with intensive silviculture that synergizes enrichment planting with pruning, commercial thinning and tebang butuh through schemes: 1) Agroforestry for food, 2) Agroforestry transition from food based initial agroforestry to advanced agroforestry and 3) Initial agroforestry to advanced agroforestry acceleration. As for Ledok Wonosari and Gunung Seribu Zone through the schemes: 1) Acceleration of initial agroforestry to full teak advanced agroforestry and 2) The transition from initial agroforestry to advanced agroforestry with enrichment. This traditional silviculture technology innovation scheme is expected to be able to enhance the role of agroforestry as the last resort of forest management conducted outside the forest.

\section{Acknowledgement}

We thank the numerous people who assisted site selection, site access and materials. Those include Pak Wagiran (Nglanggeran Village), Pak Giyanto (Gari Village) and Pak Dukuh Jetis. My student Irham, Siswanto and Selma. Funding for this research was provided by the Institute for Research and Community Services, Universitas Gadjah Mada (085/Dir.Keu/KN/DIPA-UGM/2011) with competitive grant.

\section{References}

Acharya, K. P. (2006). Linking trees on farms with biodiversity conservation in subsistence farming systems in Nepal. Biodiversity Conservation, 15, 631-646. http://dx.doi.org/10.1007/s10531-005-2091-7 
Atta-Krah, K., Kindt. R., Skilton, J. N., \& Amaral, W. (2004). Managing biological and genetic diversity in

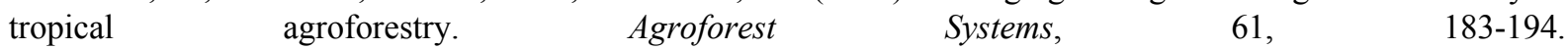
http://dx.doi.org/10.1023/B:AGFO.0000028998.32732.65

Backes, M. M. (2001). The role of indigenous trees for the conservation of biocultural diversity in traditional agroforestry land use systems: the Bungoma case study. Agroforestry Systems, 52, 119-132. http://dx.doi.org/10.1023/A:1010685317405

Berkes, F., Colding, J., \& Folke, C. (2000). Rediscovery of Traditional Ecological Knowledge as Adaptive $\begin{array}{lllll}\text { Management. } & \text { Ecological } & \text { Applications, } & 10 & \text { (5), }\end{array}$ http://dx.doi.org/10.1890/1051-0761(2000)010[1251:ROTEKA]2.0.CO;2

Gold, M. A., Rietveld, W. J., Garrett, H. E., \& Fisher, R. F. (2000). Agroforestry nomenclature, concepts, and practices for the USA. In H. E. Garrett, W. J. Rietveld, \& R. F. Fisher (Eds.), North American Agroforestry: an Integrated Science and Practice (pp. 63-76). ASA, Madison, WI.

Huxley, P. A. (1983). Plant Rsearch and Agroforestry. Published by the International Council for Research in Agroforestry. Nairobi, Kenya.

Joshi, L., Wibawa, G., Beukema, H., Williams, S., \& van-Noordwijk, M. (2003). Technological Change and Biodiversity in the Rubber Agroecosystem of Sumatra. In Vandermeer, J. (Ed.), Tropical Agroecosystems (pp. 133-157). FL, USA: CRC Press.

Joshi, L., Shrestha, P. K., Moss, C., \& Sinclair, F. L. (2004). CABI International: Locally Derived Knowledge of Soil Fertility and Its Emerging Role in Integrated Natural Resource Management. In van Noordwijk, M., Cadisch, G. dan Ong, C. K. (Eds.), Belowground Interactions in Tropical Agroecosystems: Concepts and Models with Multiple Plant Components (pp. 17-39). Wallingford, Inggris.

Joshi, L., van Noordwijk, M., \& Sinclair, F. L. (2005). Bringing Local Knowledge in Perspective: A Case of Sustainable Technology Development in Jungle Rubber Agroforests in Jambi, Indonesia. In Neef, A. (Ed.), Participatory Approaches for Sustainable Land Use in Southeast Asia (pp. 277-289). Bangkok, Thailand: White Lotus Press.

Leakey, R., Tchoundjeu, Z., Schreckenberg, K., Simons, T., Shackleton, S., Mander, M., Wynberg, R., Shackleton, C., \& Sullivan, C. (2006). Trees and markets for agroforestry tree products: targeting poverty reduction and enhanced livelihoods. In D. Garrity, A. Okono, M. Grayson, \& S. Parrott (Eds.), World Agroforestry into the Future (pp. 11-22). Nairobi, Kenya: World Agroforestry Centre.

McNeely, J. A., \& Schroth, G. (2006). Agroforestry and biodiversity conservation-traditional practices, present dynamics, and lessons for the future. Biodiversity Conservation, 15, 549-554. http://dx.doi.org/10.1007/s10531-005-2087-3

Montagu, K. D., Kearney, D. E., \& Smith, R. G. B. (2003). The biology and silviculture of pruning planted eucalypts for clear wood production-a review. Forest Ecology and Management, 179, 1-13. http://dx.doi.org/10.1016/S0378-1127(02)00579-0

Mulyoutami, E., Stefanus, E., Schalenbourg, W., Rahayu, S., \& Joshi, L. (2004). Local farmers' knowledge and Innovation Ecology in conservation and land management in the Agriculture-based Coffee in Sumberjaya, Lampung Barat. Agrivita, 26, 98 -107.

Olson, R. K., Schoeneberger, M. M., \& Aschmann, S. G. (2000). An ecological foundation for temperate agroforestry. In H. E. Garrett, W. J. Rietveld, \& R. F. Fisher (Eds.), North American Agroforestry: An Integrated Science and Practice (pp. 31-61). Madison, WI: American Society of Agronomy.

Oke, D. O., \& Odebiyi, K. A. (2007).Traditional cacao-based agroforestry and forest species conservation in Ondo State, Nigeria. Agriculture, Ecosystems \& Environment, 122, 305-311. http://dx.doi.org/10.1016/j.agee.2007.01.022

Ouinsavi, C. Sokpon, N., \& Bada, S. O. (2005). Utilization and traditional strategies of in situ conservation of iroko (Milicia excelsa Welw. C.C. Berg) in Benin. Forest Ecology and Management, 207, 341-350.

Roshetko, J. M., \& Manurung, G. E. S. (2009). Smallholder Teak Production Systems in Gunung Kidul, Indonesia. The 2 World Congress of Agroforestry. Nairobi, 24-28 August 2009.

SAS Institute Inc. (1990). SAS/STAT Users Guide. SAS Publishing, North Caroline, USA.

Sanchez, P. A. (1995). Science in Agroforestry. Agroforesry system, 30, 5-55. 
Scholes, R. J., \& Walker, B. H. (1993). An African Savanna:Synthesis of the Nylsvley Study. New York: Cambridge University Press. http://dx.doi.org/10.1017/CBO9780511565472

Shelton, D. P., Wilke, R. A., \& Franti, T. G. (2009). Farmlink: promoting conservation buffers farmer-to-farmer. Agroforest Systems, 75, 83-89. http://dx.doi.org/10.1017/CBO9780511565472

Suryanto, P., Zaki, M. H., Azmy, M., \& Azani, M. A. (2011a). Silviculture Agroforestry Regime: Compatible Management in Southern Gunung Merapi National Park, Java, Indonesia. International Journal of Biology, 3 (2), 115-126. http://dx.doi.org/10.5539/ijb.v3n2p115

Suryanto, P., Zaki, M. H., Azmy, M., \& Azani, M. A. (2011b). Exploring the Potential of Silviculture Agroforestry Regime as a Compatible Management in Southern Gunung Merapi National Park, Java, Indonesia Journal of Sustainable Development, 4 (3), 81-93. http://dx.doi.org/10.5539/jsd.v4n3p81

Suryanto, P., Zaki, M. H., Azmy, M., \& Azani, M. A. (2010). Impact of community intervention on grass stock at Gunung Merapi National Park (Southern), Java, Indonesia. Research in Environmental and Life Science, 3(3), 123-132.

Suryanto, P., Sabarnurdin, M. S., \& Tohari. (2005). Resouces Sharing Dynamics in Agroforestry Systems: Basic Consideration in Arrangement Strategy Silviculture. Jurnal Ilmu Pertanian. 12 (2), 168-181.

Suryanto, P., Sabarnurdin, M. S., \& Tohari. (2006). Resources Sharing Mahagoni and Acacia in Agroforestry System. Agrosains, 19 (13), 237-246.

Thaman, R. R. (1989). Rainforest Management within Cintex of Existing Agroforestry Systems. In Heuveldop, J., T. Homola, H.-J. von Maydell, T. van Tuyll (Eds.), Proceeding GTZ Regional Seminar. Korolevu (Fiji).

Tohari. (2004). Mixed Planting Systems a Startegy of Agronomic Adaptive in Troical. The Inaugural Professor of Speech Collection Universitas Gadjah Mada. Agriculture Science. Gadjah Mada University Press.

Vandermeer, J. H. (2002). Tropical Agroecosystems. Boca Raton, FL: CRC Press. http://dx.doi.org/10.1201/9781420039887

Table 1. Root dry weight and microclimate conditions at ZBA (Nglanggeran), ZLW (Gari) and ZGS (Jetis)

\begin{tabular}{cccc}
\hline Root dry weight and & \multicolumn{3}{c}{ Agroforestry zone } \\
\cline { 2 - 4 } microclimate condition & Nglanggeran & Gari & Jetis \\
\hline Root dry weight $(\mathrm{g})$ & $0,29 \mathrm{a}$ & $0,25 \mathrm{a}$ & $0,14 \mathrm{a}$ \\
Temperature in the morning $\left({ }^{\circ} \mathrm{C}\right)$ & $32,07 \mathrm{c}$ & $35,78 \mathrm{a}$ & $33,74 \mathrm{~b}$ \\
Temperature in the noon $\left({ }^{\circ} \mathrm{C}\right)$ & $34,19 \mathrm{c}$ & $38,41 \mathrm{a}$ & $35,07 \mathrm{~b}$ \\
Temperature in the afternoon $\left({ }^{\circ} \mathrm{C}\right)$ & $27,70 \mathrm{c}$ & $36,85 \mathrm{a}$ & $32,63 \mathrm{~b}$ \\
Humidity in the morning $(\%)$ & $46,67 \mathrm{~b}$ & $38,19 \mathrm{c}$ & $47,81 \mathrm{a}$ \\
Humidity in the noon $(\%)$ & $43,52 \mathrm{~b}$ & $33,44 \mathrm{c}$ & $44,63 \mathrm{a}$ \\
Humidity in the afternoon (\%) & $59,00 \mathrm{a}$ & $37,85 \mathrm{c}$ & $48,37 \mathrm{~b}$ \\
Light intensity in the morning (lux) & $59859 \mathrm{~b}$ & $55344 \mathrm{c}$ & $66904 \mathrm{a}$ \\
Light intensity in the noon (lux) & $53567 \mathrm{c}$ & $78748 \mathrm{~b}$ & $85170 \mathrm{a}$ \\
Light intensity in the afternoon (lux) & $11362 \mathrm{c}$ & $32344 \mathrm{~b}$ & $51811 \mathrm{a}$ \\
\hline
\end{tabular}

Means in the same row, followed by different letters, are significantly different, based on the DMRT $(p \leq 0.05)$ 
Table 2. Soil moisture content, $\mathrm{pH}$, total $\mathrm{N}$, available $\mathrm{P}$, available $\mathrm{K}$, available $\mathrm{Ca}$, available $\mathrm{Mg}$, clay, dust and sand fraction in the Nglanggeran, Gari and Jetis zones

\begin{tabular}{cccc}
\hline \multirow{2}{*}{ Soil analysis variable } & \multicolumn{3}{c}{ Zona agroforestry } \\
\cline { 2 - 4 } & Nglanggeran & Gari & Jetis \\
\hline Moisture level $0.5 \mathrm{~mm}$ & $15,78 \mathrm{a}$ & $11,72 \mathrm{~b}$ & $14,36 \mathrm{ab}$ \\
Moisture level $2 \mathrm{~mm}$ & $16,68 \mathrm{a}$ & $12,37 \mathrm{~b}$ & $14,78 \mathrm{ab}$ \\
$\mathrm{pH} \mathrm{H} \mathrm{H}_{2} \mathrm{O}$ & $5,36 \mathrm{~b}$ & $7,43 \mathrm{a}$ & $5,67 \mathrm{~b}$ \\
$\mathrm{~N}$ total & $0,13 \mathrm{~b}$ & $0,11 \mathrm{c}$ & $0,17 \mathrm{a}$ \\
$\mathrm{P}$ available & $9,71 \mathrm{a}$ & $4,61 \mathrm{a}$ & $4,31 \mathrm{a}$ \\
K available & $0,63 \mathrm{a}$ & $0,15 \mathrm{a}$ & $0,32 \mathrm{a}$ \\
Ca available & $5,73 \mathrm{c}$ & $14,21 \mathrm{a}$ & $8,25 \mathrm{~b}$ \\
Mg available & $4,13 \mathrm{a}$ & $2,82 \mathrm{~b}$ & $3,17 \mathrm{~b}$ \\
Clay fraction & $41,19 \mathrm{c}$ & $64,53 \mathrm{~b}$ & $88,29 \mathrm{a}$ \\
Dust fraction & $26,46 \mathrm{a}$ & $17,89 \mathrm{~b}$ & $9,37 \mathrm{c}$ \\
Sand fraction & $32,35 \mathrm{a}$ & $17,58 \mathrm{~b}$ & $2,34 \mathrm{c}$ \\
\hline
\end{tabular}

Means in the same row, followed by different letters, are significantly different, based on the DMRT $(p \leq 0.05)$

Table 3. Root dry weight and microclimate condition in initial, intermediate, and advanced stages

\begin{tabular}{cccc}
\hline \multirow{2}{*}{ Root dry weight and microclimate condition } & \multicolumn{3}{c}{ Agroforestry Stages } \\
\cline { 2 - 4 } & Initial & Intermediate & Advanced \\
\hline Root dry weight $(\mathrm{g})$ & $0,09 \mathrm{~b}$ & $0,28 \mathrm{a}$ & $0,31 \mathrm{a}$ \\
Temperature in the morning $\left({ }^{\circ} \mathrm{C}\right)$ & $36,00 \mathrm{a}$ & $33,15 \mathrm{~b}$ & $32,44 \mathrm{c}$ \\
Temperature in the noon $\left({ }^{\circ} \mathrm{C}\right)$ & $36,93 \mathrm{a}$ & $35,89 \mathrm{~b}$ & $34,85 \mathrm{c}$ \\
Temperature in the afternoon $\left({ }^{\circ} \mathrm{C}\right)$ & $33,37 \mathrm{a}$ & $32,37 \mathrm{~b}$ & $31,44 \mathrm{c}$ \\
Humidity in the morning $(\%)$ & $40,33 \mathrm{c}$ & $45,41 \mathrm{~b}$ & $46,93 \mathrm{a}$ \\
Humidity in the noon $(\%)$ & $38,48 \mathrm{c}$ & $40,19 \mathrm{~b}$ & $42,93 \mathrm{a}$ \\
Humidity in the afternoon $(\%)$ & $46,59 \mathrm{c}$ & $48,85 \mathrm{~b}$ & $49,78 \mathrm{a}$ \\
Light intensity in the morning $($ lux $)$ & $89074 \mathrm{a}$ & $49896 \mathrm{~b}$ & $43137 \mathrm{c}$ \\
Light intensity in the noon (lux) & $93878 \mathrm{a}$ & $67759 \mathrm{~b}$ & $55848 \mathrm{c}$ \\
Light intensity in the afternoon (lux) & $42756 \mathrm{a}$ & $30392 \mathrm{~b}$ & $22370 \mathrm{c}$ \\
\hline Means in the same row, followed by different letters, are significantly different, based on the DMRT $(p \leq 0.05)$
\end{tabular}


Table 4. Root dry weight and microclimate conditions in the open, semi open and under the stand zone

\begin{tabular}{cccc}
\hline \multirow{2}{*}{ Root dry weight and microclimate condition } & \multicolumn{3}{c}{ Zone } \\
\cline { 2 - 4 } & Open & Semi open & $\begin{array}{c}\text { Under the } \\
\text { stand }\end{array}$ \\
\hline Root dry weight $(\mathrm{g})$ & $0,15 \mathrm{a}$ & $0,28 \mathrm{a}$ & $0,25 \mathrm{a}$ \\
Temperature in the morning $\left({ }^{\circ} \mathrm{C}\right)$ & $35,11 \mathrm{a}$ & $33,63 \mathrm{~b}$ & $32,85 \mathrm{c}$ \\
Temperature in the noon $\left({ }^{\circ} \mathrm{C}\right)$ & $37,04 \mathrm{a}$ & $35,44 \mathrm{~b}$ & $35,19 \mathrm{~b}$ \\
Temperature in the afternoon $\left({ }^{\circ} \mathrm{C}\right)$ & $32,89 \mathrm{a}$ & $32,52 \mathrm{~b}$ & $31,78 \mathrm{c}$ \\
Humidity in the morning $(\%)$ & $42,04 \mathrm{c}$ & $44,59 \mathrm{~b}$ & $46,04 \mathrm{a}$ \\
Humidity in the noon (\%) & $39,44 \mathrm{c}$ & $41,30 \mathrm{a}$ & $40,85 \mathrm{a}$ \\
Humidity in the afternoon (\%) & $48,07 \mathrm{~b}$ & $47,89 \mathrm{~b}$ & $49,26 \mathrm{a}$ \\
Light intensity in the morning (lux) & $82141 \mathrm{a}$ & $59104 \mathrm{~b}$ & $40863 \mathrm{c}$ \\
Light intensity in the noon (lux) & $106785 \mathrm{a}$ & $66030 \mathrm{~b}$ & $44670 \mathrm{c}$ \\
Light intensity in the afternoon (lux) & $40056 \mathrm{a}$ & $32415 \mathrm{~b}$ & $23047 \mathrm{c}$
\end{tabular}

Means in the same row, followed by different letters, are significantly different, based on the DMRT $(p \leq 0.05)$

Agroforestry pattern based on canopy thickness

$0 \% \quad$ visualized grayscale color gradient range $\quad 100 \%$
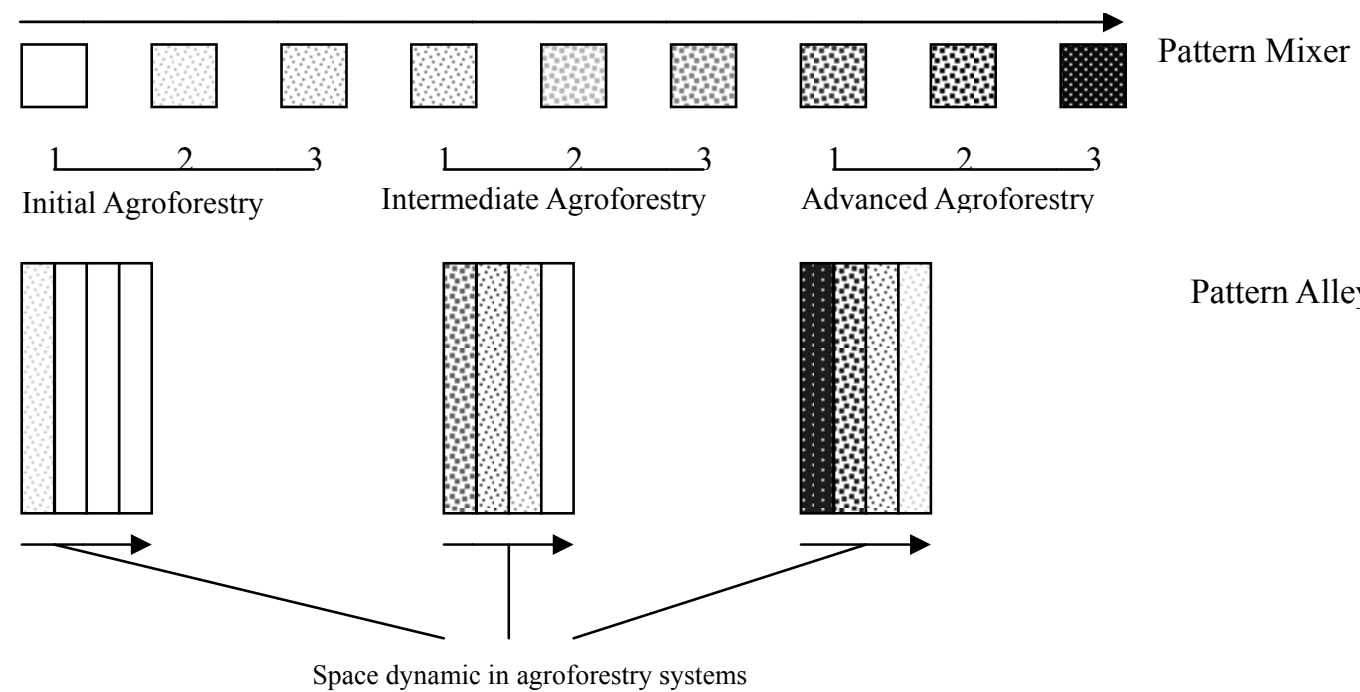

Pattern Alley

Figure 1. Agroforestry classification based on the development of spatial structure (thickness) in land vegetation (Suryanto et al., 2006)

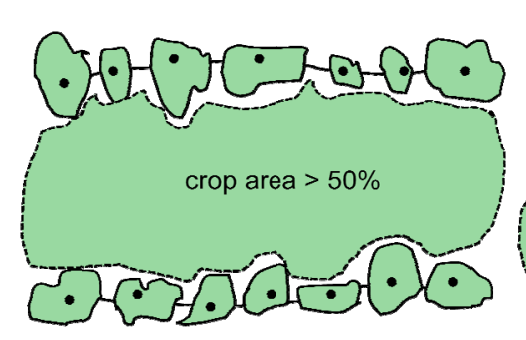

Initial Agroforestry

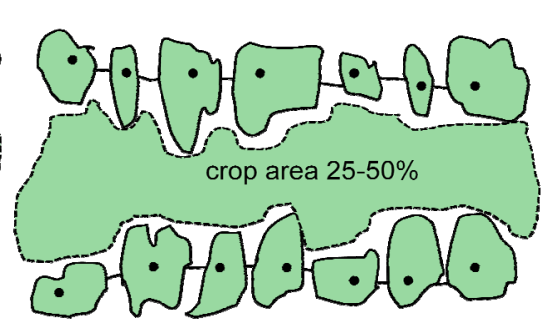

Intermediate Agroforestry

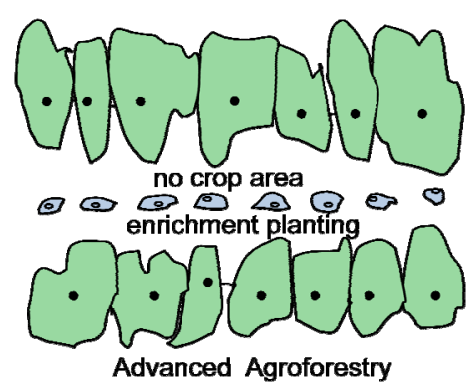

Advanced Agroforestry

Figure 2. Typology of initial, intermediate, and advanced agroforestry in Gunungkidul 


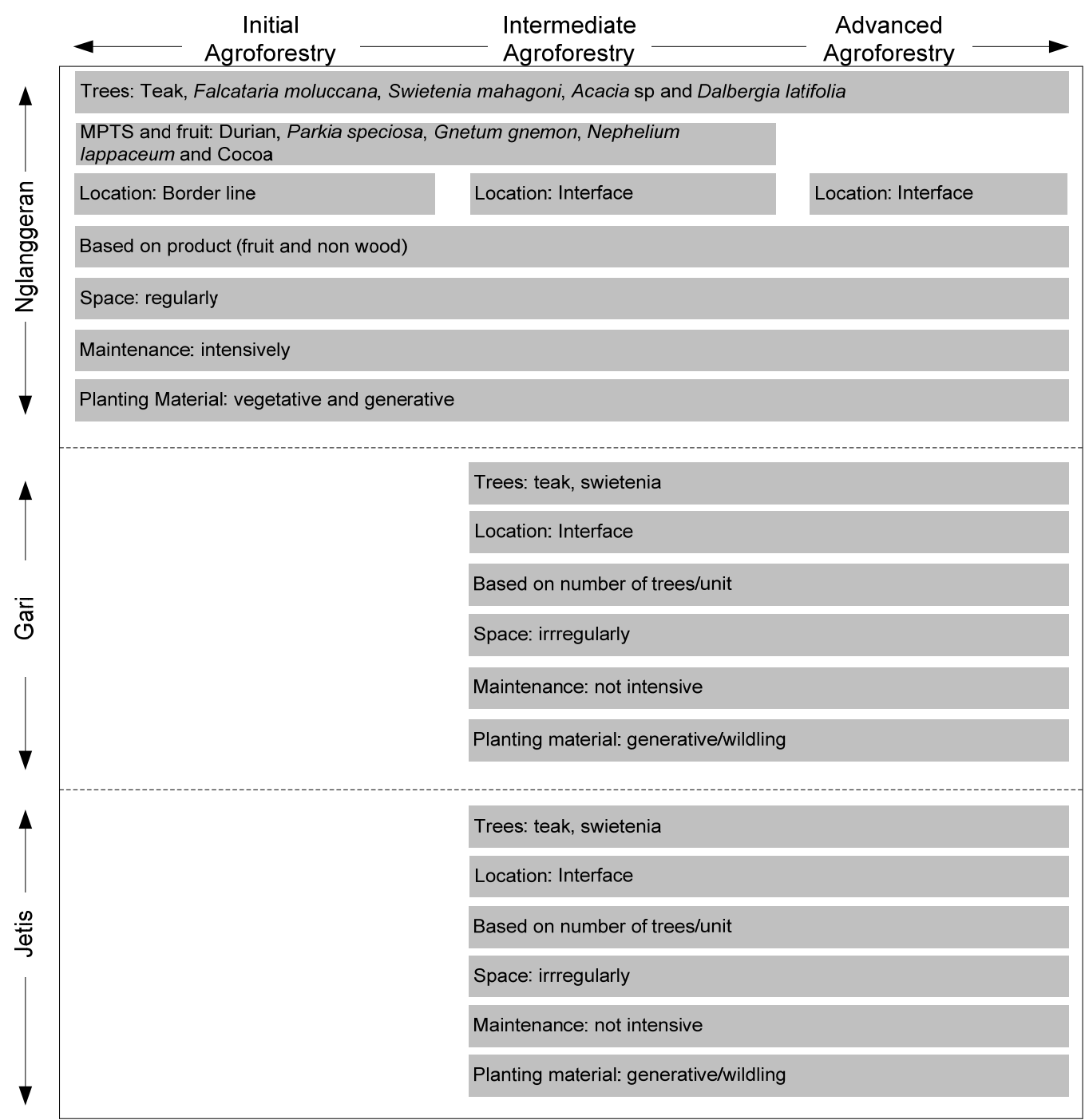

Figure 3. Characteristic enrichment planting at different types of agroforestry in Gunungkidul

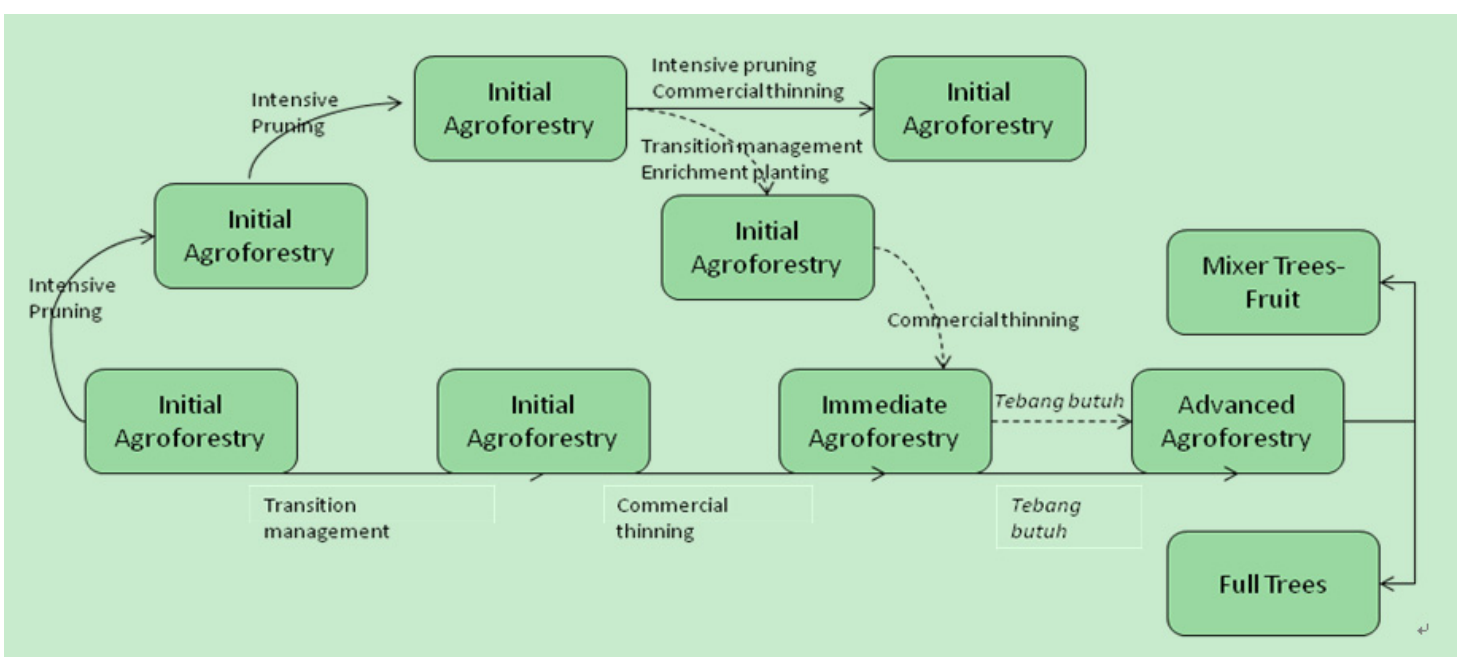

Figure 4. Enrichment planting strategy in the Nglanggeran Village 


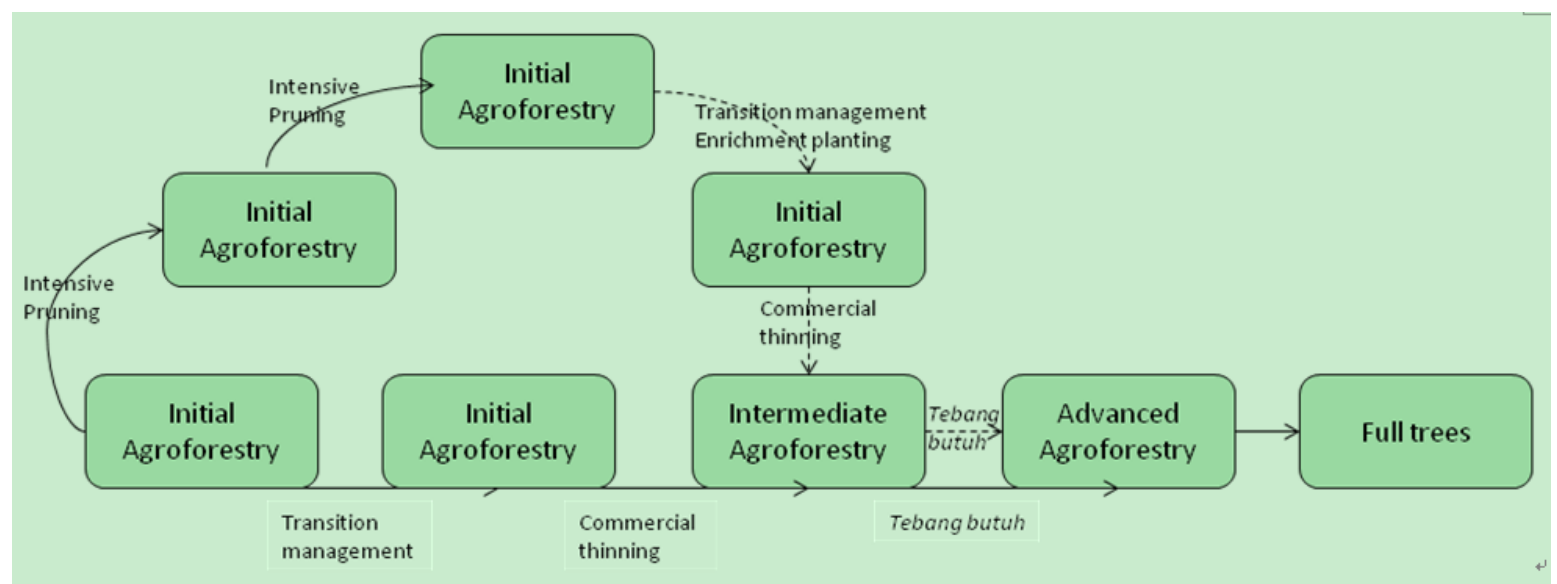

Figure 5. Enrichment planting strategy types in the village of Gari and Jetis 